\title{
Effect of phytoremediation on the morpho-anatomical characters of some aquatic macrophytes
}

\author{
JONES T. NAPALDET ${ }^{1, \bullet}$, INOCENCIO E. BUOT Jr. ${ }^{2}$, MACRINA T. ZAFARALLA ${ }^{2}$, IRENEO L. LIT Jr ${ }^{2}$, \\ RACHEL C. SOTTO ${ }^{2}$ \\ ${ }^{1}$ Department of Biology, Benguet State University, Km. 6, La Trinidad, Benguet 2601, Philippines. \\ `email: jtnapaldet@up.edu.ph. \\ ${ }^{2}$ Institute of Biological Sciences, University of the Philippines Los Baños. Losa Banis 4031, Philippines
}

Manuscript received: 16 December 2018. Revision accepted: 20 April 2019.

\begin{abstract}
Napaldet JT, Buot Jr. IE, Zafaralla MT, Lit Jr. IL, Sotto RC . 2019. Effect of phytoremediation on the morpho-anatomical characters of some aquatic macrophytes. Biodiversitas 20: 1289-1302. In constructed wetland studies, the effect of pollutants or the phytoremediation set-up on aquatic macrophytes is often not investigated. This literature gap may prove useful in realizing the full phytoremediation potential of aquatic macrophytes. This study was conducted to examine the effect of phytoremediation, the set-up, and the pollutants, on the morpho-anatomical characters of aquatic macrophytes used in the constructed wetlands. This was investigated in Amaranthus spinosus, Eichhornia crassipes, Eleusine indica, and Pennisetum purpureum. Simultaneously, interesting anatomical features in the aquatic macrophytes were discovered. Anomalous secondary growth was discovered in roots and stems of A. spinosus while isobilateral anatomy of the leaf with two layers of vascular bundles and two palisade layers under each epidermis were noted in $E$. crassipes. The anatomy of $P$. purpureum was also first reported here. Results showed that the response of the aquatic macrophytes toward phytoremediation treatments was species-specific. E. indica and $P$. purpureum were the ones significantly affected by the phytoremediation treatment in contrasting ways. E. indica under phytoremediation suffered significantly lower growth rate than those in the uncontaminated site which could be attributed to the inability of its relatively short root system to tap into the water and nutrients. On the other hand, $P$. purpureum exhibited higher biomass and growth rate under phytoremediation treatment which is primarily due to the water pollutants absorbed as nutrients by the plant. There were no structural differences observed in the anatomy of the aquatic macrophytes between sampling sites except in E. indica. The root's cortex in samples under phytoremediation has no aerenchyma while this is present in uncontaminated site and Balili River samples. This shows that, indeed, some aquatic macrophytes were significantly affected $(\mathrm{p}=0.00)$ by phytoremediation that should be taken in consideration when planning and designing constructed wetlands.
\end{abstract}

Keywords: Amaranthus spinosus, Eichhornia crassipes, Eleusine indica, morpho-anatomical, Pennisetum purpureum, phytoremediation

\section{INTRODUCTION}

Phytoremediation, an emerging cost-effective, nonintrusive, and aesthetically pleasing technology, that uses the remarkable ability of plants to concentrate elements and compounds from the environment and to metabolize various molecules in their tissues, appears very promising for the removal of pollutants from the environment (Alkorta et al. 2004; Tulod et al. 2012). Several plants had been documented to be ideal or viable phytoremediators in mine tailings such as Armeria maritima, Ambrosia artemisiifolia, Brassica juncea, Brassica napus, Brassica oleracea, Festuca ovina, Helianthus annuus, Thalspiro tundifolium, Triticum aestivum, Zea mays, among those reported and in constructed wetlands, usually Typha spp. and Phragmites australis had been reported. In another publication, the authors reported the promising potential of Amaranthus spinosus, Eichhornia crassipes, Eleusine indica and Pennisetum purpureum for phytoremediation of Balili River in La Trinidad, Benguet, Philippines.

Usually, phytoremediation studies are primarily focused on the pollution reduction action of the pants, with less emphasis on the effect of the pollutant or phytoremediation set-up to the plants themselves (ala landscape ecology). In mine tailings or heavy metal studies, some efforts have been conducted to document the effects of the heavy metals to the growth and anatomy of the plants. For example, Bini et al. (2012) discovered significant reduction in the leaf thickness, changes in intercellular spaces and in cell structural organization in Taraxacum officinale growing on mixed sulfides $(\mathrm{Cu}, \mathrm{Fe}, \mathrm{Pb}, \mathrm{Zn})$ mine waste.

But in constructed wetland studies, none was cited examining the effects of the phytoremediation, either the set-up or the pollutants, to the aquatic macrophytes used. This shows a glaring gap in literature documenting how aquatic macrophytes adopt or cope with the stress brought by pollutants introduced in the constructed wetlands. It's universally known that plants have the natural ability to adapt to physical and chemical changes in their environment but with the environment increasingly being dominated by human, several man-made stresses are now besetting these plant (Mganga 2011). Understanding the effect of phytoremediation treatments, as stress, on aquatic macrophytes is vital in designing a set-up that would minimize the detrimental stress on the plants while at the same time realizing the full phytoremediation potential of the plants which would result to more efficient clean-up of the contaminants. Thus this study was conceptualized to 
examine the effects of phytoremediation on the morphoanatomical characters of A. spinosus, E. crassipes, E. indica, and $P$. purpureum. This endeavor also yielded important anatomical characterization of the said species as these were not yet addressed in existing literature.

\section{MATERIALS AND METHODS}

\section{Sampling of aquatic macrophytes and the phytoremediation treatment}

Individuals of $A$. spinosus, E. crassipes, E. indica and $P$. purpureum used in the phytoremediation study were derived from uncontaminated sites. For A. spinosus, E. indica and $P$. purpureum, individuals were derived from Barangay Tawang while individuals of E. crassipes were gathered from nearby pond in Tabangaoen, Balili, La Trinidad, the Philippines (Figure 1). These macrophytes were planted in pilot-scale constructed wetlands to determine their phytoremediation performance in improving the water quality of Balili River. Each macrophyte was planted in individual constructed wetland $(\mathrm{CW})$, of which the design was patterned after Bai et al.'s (2016) study.
After acclimatizing the plants in the $\mathrm{CW}$, wastewater from Balili River was allowed to flow in it and thereby allowing the macrophytes to absorb the pollutants in the water. To determine the phytoremediation performance of the plant, the water quality before and after the water pass through the $\mathrm{CW}$ was assessed and the pollution reduction efficiency was determined. The performance of these macrophytes and the details of the pilot-scale constructed wetlands were reported in another article.

After observing the phytoremediation performance of the macrophytes for 2 months, samples from the treatment sites (hereto referred to $\operatorname{TrA}$ samples) were gathered for morpho-anatomical characterization. Simultaneously, samples of same species were gathered from the source uncontaminated sites (hereto referred as Uncon samples) and from Balili River (hereto referred as Balili samples), except for E. crassipes which does not naturally occur in Balili River. The morpho-anatomical characterization was compared between the three samples with the assumption that such comparison would show the possible effects of the phytoremediation treatment to the macrophytes themselves.

\section{LOCATION OF STUDY SITES}

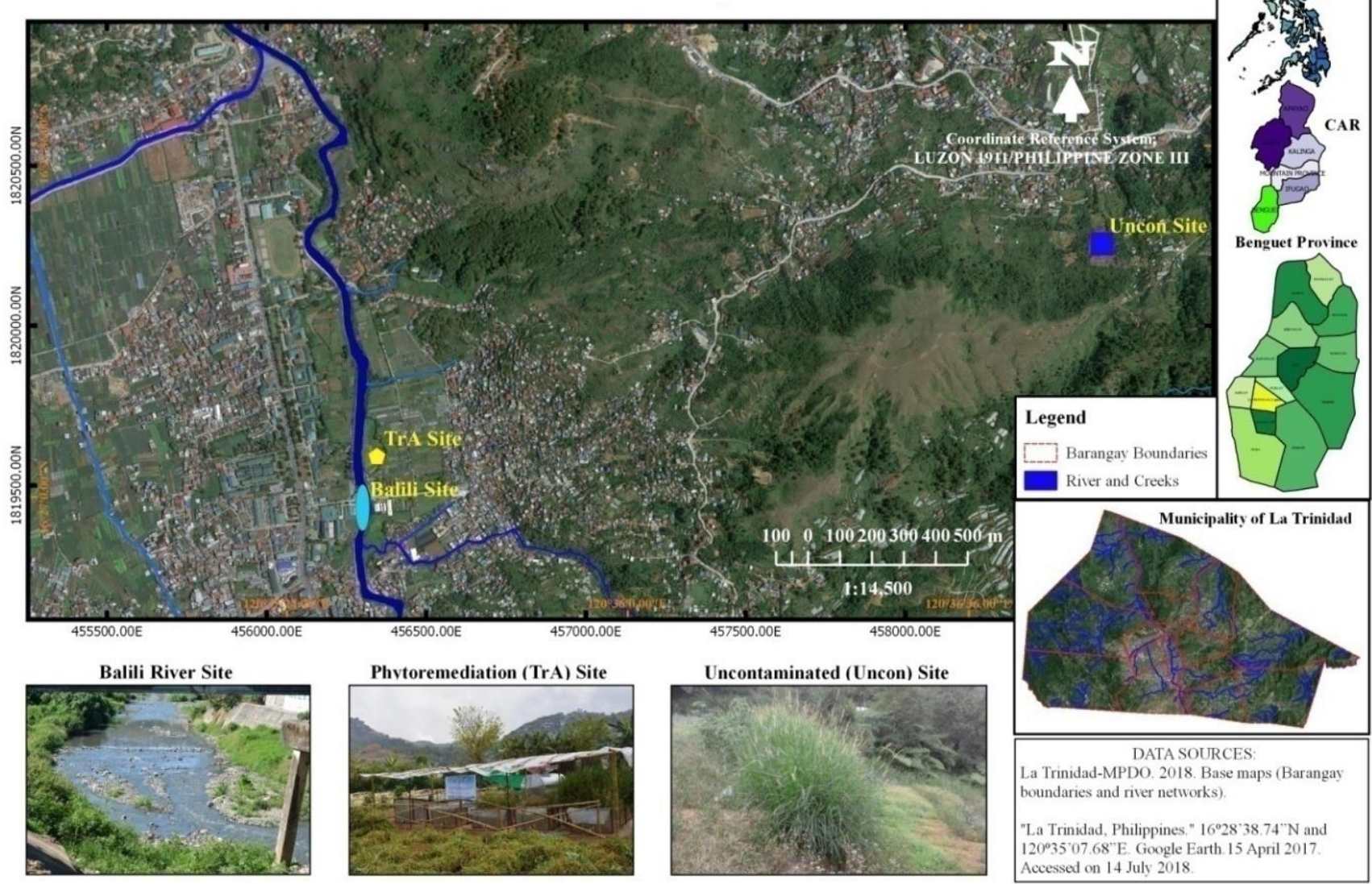

Figure 1. Location of the study area showing the three sampling sites nearby pond in Tabangaoen, Balili, La Trinidad, the Philippines 


\section{Morpho-anatomical characterization}

Several morphological and anatomical features of the test plants were compared between the three sampling sites. These could serve as the plant's functional traits that may indicate how these macrophytes respond to pollutants in the constructed wetland. These include certain leaf, stem and root measurements. For the leaf, length, width, leaf area, specific leaf area, leaf thickness, and stomatal density were measured. Stem or culm diameter was also measured. For the root, specific root length, maximum rooting depth, lateral extent, and intensity of exploration were measured. These parameters were determined following the standardized measurement of plant functional traits developed by Perez-Harguindeguy et al. (2013). The minimum required 5 individuals or samples per test plants were followed in the study.

For anatomical investigation, cross-sections of the different plant organs were derived and observed under light microscopy. Anatomical features of the plants were compared among test individuals vs. individuals found in the river vs. individuals in uncontaminated sites.

\section{Data analysis}

Data gathered were subjected to appropriate statistical analyses such as Analysis of Variance (ANOVA) which determined significant differences between treatments followed by Tukey's HSD, as a Post Hoc Test. Additionally, Canonical Correspondence Analysis was performed in $P$. purpeum only to determine the environmental factors that affected its morpho-anatomical traits in the different collection site.

\section{RESULTS AND DISCUSSION}

\section{Morpho-anatomical characterization of the local aquatic macrophytes}

The morpho-anatomical features of the local aquatic macrophytes were first discussed as these were not yet addressed in available literature amidst their prevalence and economic and ecological importance.

\section{Eichhornia crassipes (Mart) Solms.}

The plant is floating herb with short leafy stem and fibrous black roots. Leaves are radical, rosulate; petiole spongy and bulbous in or near the middle; blade broadly ovate or rhomboid; base cordate, truncate, rounded or broadly cuneate; apex rounded, truncate or emarginated; fine and densely curvi-nerved.

Anatomical characterization of E. crassipes in the study provided detailed features of the plant as there was very few literatures describing it amidst the widely recognized economic and ecological importance of the plant. Hanif et al. (2017) initially described this plant but only superficially not including the cross-section (x.s) of the leaf, offshoot, and the roots. In this study, cross sections of the root showed a typical monocotyledon root (Figure 2.F). The epidermis, consists of single layer of rectangular cells, forms the outermost covering followed by a wide cortex, then the vascular cylinder. The cortex consists of 3-4 layers of hexagonal, large parenchyma cells followed by a wide expanse of aerenchyma tissues, then by 3-5 layers of smaller circular parenchyma. After the cortex lies the endodermis, composed of a single layer of cells lined with Casparian strip. However, the Casparian strip in $E$. crassipes is not as prominent as those commonly observed in monocot roots. This would most likely result in faster absorption of materials (water, nutrient, including heavy metals) which could help account for the plant's fast growth rate and its ability to absorb and accommodate pollutants. Within the endodermis is the stele which is composed of pericycle, vascular bundles, and pith. The pericycle consists of a single layer of meristematic cells that give rise to lateral roots. The vascular bundles consist of alternating phloem with exarch xylem surrounding a well-defined pith. Metaxylem elements are located at inner portion with the protoxylem at the outer portion.

The offshoot (Figure 2.E), a modified stem for asexual reproduction of new individuals, exhibits the common atactostele arrangement with some modifications. The single-layer epidermis covered with thick cuticle forms the outermost covering, followed by ground tissues that is interspersed with vascular bundles. But unlike common monocot stem, there are several air spaces in the ground tissues and at the central portion, the parenchyma cells are laden with starch grains which are most likely supplied to the growing bud at the tip of the offshoot. The bulbous petiole (Figure 2.D) is similar in structure except that the air spaces are more extensive and interconnected forming aerenchyma tissues. Layers of photosynthetic cells are observed under the epidermis which signifies that the bulbous petiole did not only function for aeration and flotation but also for photosynthesis.

The leaf of E. crassipes (Figure 2.C) exhibits isobilateral anatomy where there are two palisade layers under each epidermis, a trait uncommon in monocot leaf. Each palisade layer is composed of elongated tightly packed cells, but the upper palisade layer has longer and more layer of cells. The presence of two parallel palisade layers enables the plant to maximize photosynthesis with the upper palisade capturing sunlight directly while the lower palisade captures light reflected by the water. This could be one of the traits that account for the plant's success. The spongy layer with large air spaces is located in the middle. These air spaces are connected to the aerenchyma tissues of the bulbous petiole and roots. Another interesting, if not unique, feature of the leaf is the presence of two layers of vascular bundles, each associated with the parallel palisade layers. Usually, plants have one layer of vascular bundles traversing the mesophyll. The stomata in the upper (Figure 2.A) and lower (Figure 2.B) epidermis are of anomocytic type, where stomata are surrounded by limited number of subsidiary cells which are quite alike the remaining cells. Anomocytic type was also reported in plants of family Liliaceae, Boraginaceae, Ranunculaceae, and Geraniaceae. 

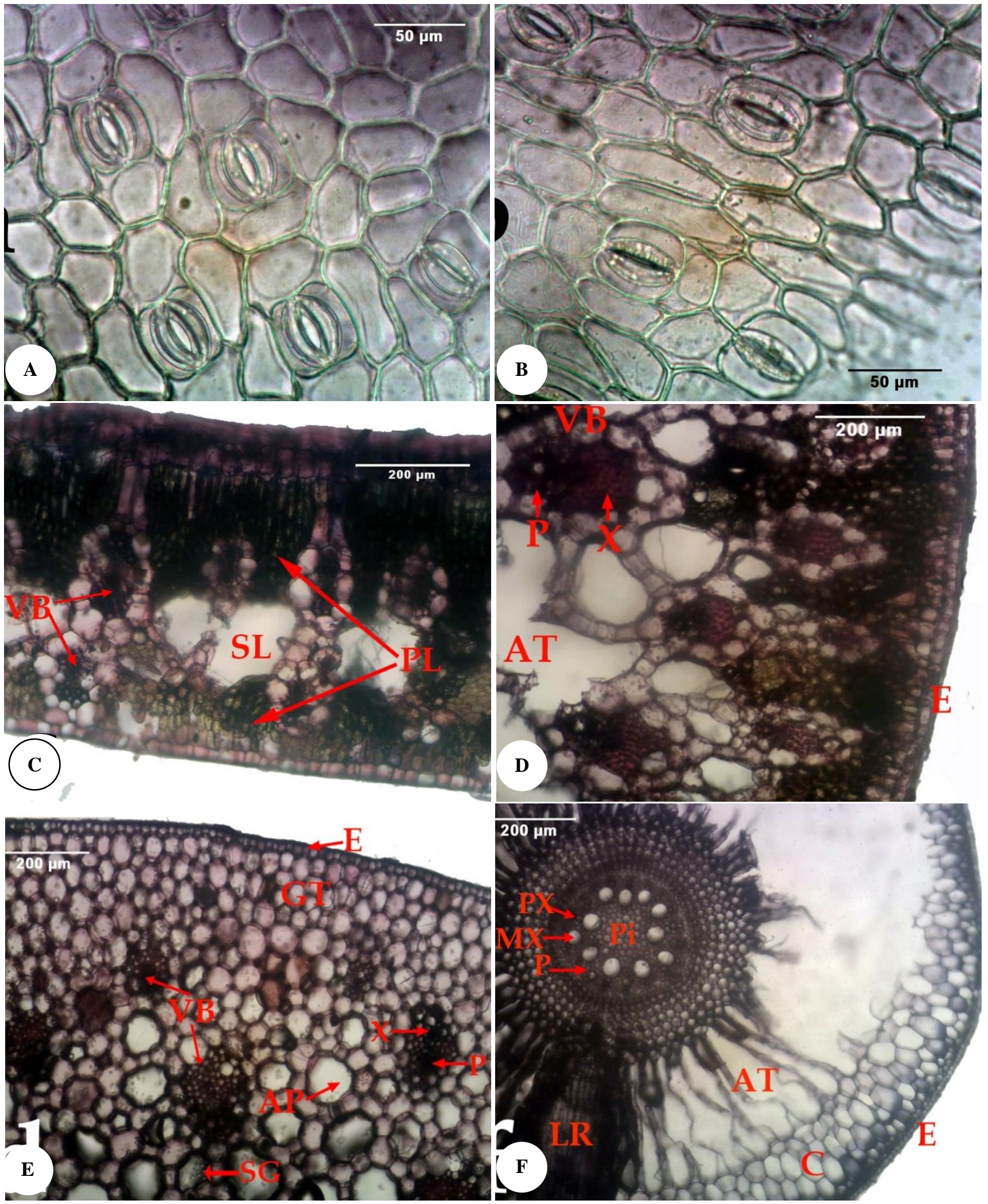

Figure 2.A-F. Anatomical features of Eichhornia crassipes showing the adaxial (A) and abaxial (B) epidermis, leaf x.s. (C), bulbous petiole x.s (D), offshoot x.s.(E) and root x.s. (F) (AT: aerenchyma tissues; AP- air space; C-cortex; E: epidermis; GT: ground tissues; LR: lateral roots; MX: metaxylem; P:phoem; Pi: pith; PX: protoxylem; SG: starch grains; SL: spongy layer; VB: vascular bundles; X: xylem) 

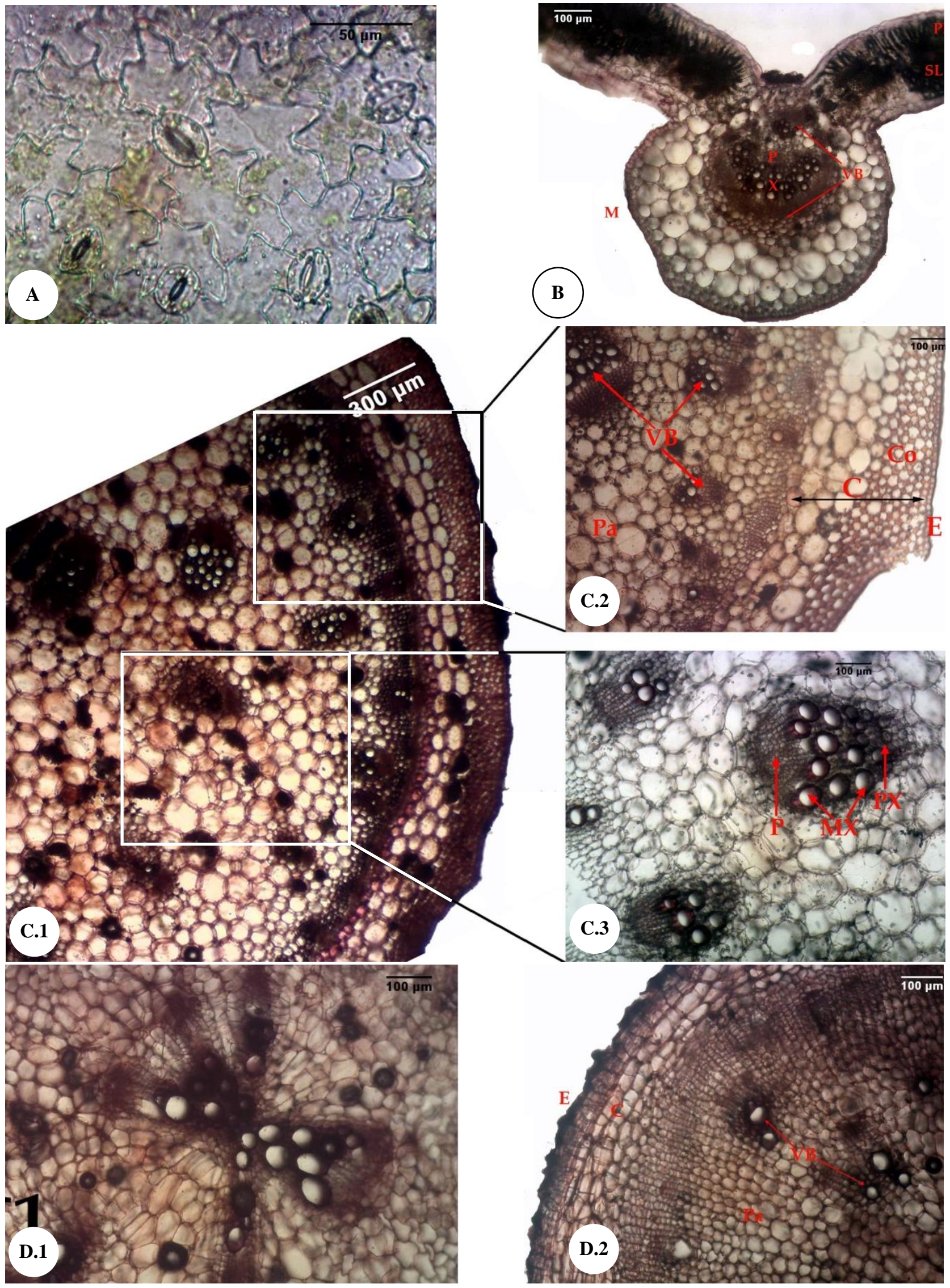

Figure 3.A-D. Anatomical features of Amaranthus spinosus showing the abaxial epidermis (A), leaf x.s. (B), stem X.s (C) and root x.s.(D) (C: cortex; Co: collenchymas; E: epidermis; MX: metaxylem; P: phoem; Pa: parenchyma; PL: palisade layer; PX: protoxylem; SL: spongy layer; VB: vascular bundles; X: xylem) 
Amaranthus spinosus $\mathrm{L}$.

Samples of A. spinosus used in the study were consistent with the earlier description by Pancho and Obien (1995). It is a stout, glabrous, branched annual armed with slender axillary spines and with well-defined taproot system. Leaves exstipulate, long-petioled, oblong to ovate to elliptic; base obtuse; apex acute; margin undulates. Flowers in axillary clusters or elongated terminal dense spike, green or greenish white, the setaceous bracts as long or longer than the five sepals, ovary oblong; styles usually 3 , sometimes 2 .

Its anatomical characterization proved to be timely since this was not yet thoroughly addressed in existing literature. The root and stem exhibited anomalous secondary growth of successive supernumerary cambia pattern that is similar with Beta vulgaris (Rapoport and Loomis 1986). Embedded cambia in the pith-like parenchymatous core give rise to scattered vascular bundles surrounded by large parenchyma cells (Figure 3.CD). The root (Figure 3. $D_{1 \& 2}$ ) is covered by a single-layered epidermis followed by parenchymatous cortex. Within the cortex is the pith-like parenchymatous core with few scattered vascular bundles (Figure 3.D $_{1}$ ) but the middlemost portion is occupied by xylem elements (Figure 3.D $\mathrm{D}_{2}$ ). The anomalous secondary growth is more prominent in older roots as they have greater successively-arranged layers of vascular bundles between parenchyma layers.

The stem is also covered by a single-layered epidermis followed by the cortex (Figure 3.C). The cortex consists of 4-5 layers of thick-walled collenchyma followed by 2-3 layers of large parenchyma. After the cortex is the ring-like vascular bundles and within that, the anomalous secondary growth is observed where vascular bundles are scattered within a pith-like parenchymatous core. This structure is similar to Amaranthus viridis described by Warif et al. (2014) but they failed to account for the anomalous secondary growth. On the other hand, the leaf exhibits an undivided mesophyll which is uncommon in dicots (Figure 3.B). The midrib is conspicuous with 2-4 vascular bundles separated by large parenchyma cells. The stomata are of ranunculaceous type where the stomata are surrounded by irregularly-shaped cells (Figure 3.A).

\section{Eleusine indica (L.) Gaertn.}

The plant is a stout, tufted, erect glabrous annual with fibrous root system. Leaves linear, sometimes involute when dry, distichous, rather flaccid, the sheaths flattened. Flowers in terminal spike, whorled or one or two down; spikelets very numerous, crowded, 3-5 flowered, the first glume 1-nerved, small, the second 3-nerved, the third and succeeding ones ovate, acute.

Anatomical characterization of E. indica revealed siphonostele roots, atactostele stem and an undivided mesophyll in the leaf. The root (Figure 4.C) exhibits a typical monocot root with a uniseriate epidermis as the outermost cover, followed by a parenchymatous cortex, then the stele. Several root hairs arise from the epidermis. The three samples differ in their cortex with Uncon and Balili samples (Figure 4.C $C_{1}$ ) having wide stretch of aerenchyma tissues while $\mathrm{TrA}$ samples (Figure $4 . \mathrm{C}_{3}$ ) have normal parenchymatous cortex. The endodermis, the innermost layer of the cortex, is distinct but lined only with limited layer of suberin (Figure 4.C $C_{2}$ ). This is followed by the pericycle which is composed of thin, single layer of cells, then by the vascular bundles surrounding the pith at the centremost core. The vascular bundles consist of alternating series of exarch xylem and the phloem in between.

The culm (Figure 4.B) of $E$. indica exhibits a modified atactostele arrangement. The epidermis forms the outermost covering, followed by a 4-layered parenchymatous cortex, then by 4-6 layers of collenchyma (sclerenchyma in older culms as shown in Figure 4. $\mathrm{B}_{3}$ ) that forms a circular ring followed around the ground tissues. The ground tissues are embedded with closed collateral vascular bundles (Figure $4 . \mathrm{B}_{2}$ ) with greater concentration in the periphery. The centermost portion is dominated by large parenchyma cells in young culm that eventually disintegrate in mature culm forming a cavity.

The leaf (Figure 4.A), on the other hand, has undivided mesophyll with regularly-spaced vascular bundles. Each vascular bundle is surrounded by large parenchyma cells resulting in a circular bulge toward the upper epidermis giving the leaf x.s. a lobed-surface with vascular bundle under each lobe. Bulliform cells are located within the furrow between the vascular bulges. Within the vascular bundles are the xylem at the upper portion and the phloem underneath. Stomata are of gramineous type and are found at both upper (Figure 4. $\mathrm{A}_{1}$ ) and lower (Figure 4. $\mathrm{A}_{2}$ ) epidermis. At adaxial epidermis, the subsidiary cells, cork cells, and long cells are distinct. These anatomical features of $E$. indica in the study are consistent with the earlier description of Saw (2011).

\section{Pennisetum purpureum Schumach.}

A robust, perennial grass with long culms that can form thick clusters. Leaf sheaths glabrous or with tubercle-based hairs on upper surface; blade elongated, usually with short, fine tubercle-based hairs on upper surface. Inflorescence a briskly false spike up to $30 \mathrm{~cm}$ long, dense, usually yellowbrown; involucres sessile or numerous, bristles of unequal length, one usually stouter and much longer than the rest, scrabrid; spikelets $4.5-6 \mathrm{~mm}$ long, glabrous, solitary, sessile or in cluster of 2-5; glumes unequal, 1-nerved or nerveless; lower florets staminate or sterile, the lemma usually 1-3 nerved; upper lemma 5-nerved, acuminate or short-awned.

Anatomical observation of $P$. purpureum proved to be timely since this was not yet addressed in existing literature. The root (Figure 5.F) exhibits a typical monocot root with a uniseriate epidermis as the outermost cover, followed by a parenchymatous cortex, then the stele. Aerenchyma tissues were present in the cortex indicating water-logged conditions of their soil. The endodermis, the innermost layer of the cortex, is distinct from a visible Casparian strip. This is followed by the pericycle which is composed of thin, single layer of cells, then by vascular bundles surrounding the pith at the centremost core. The vascular bundles consist of alternating series of exarch xylem and the phloem in between. 


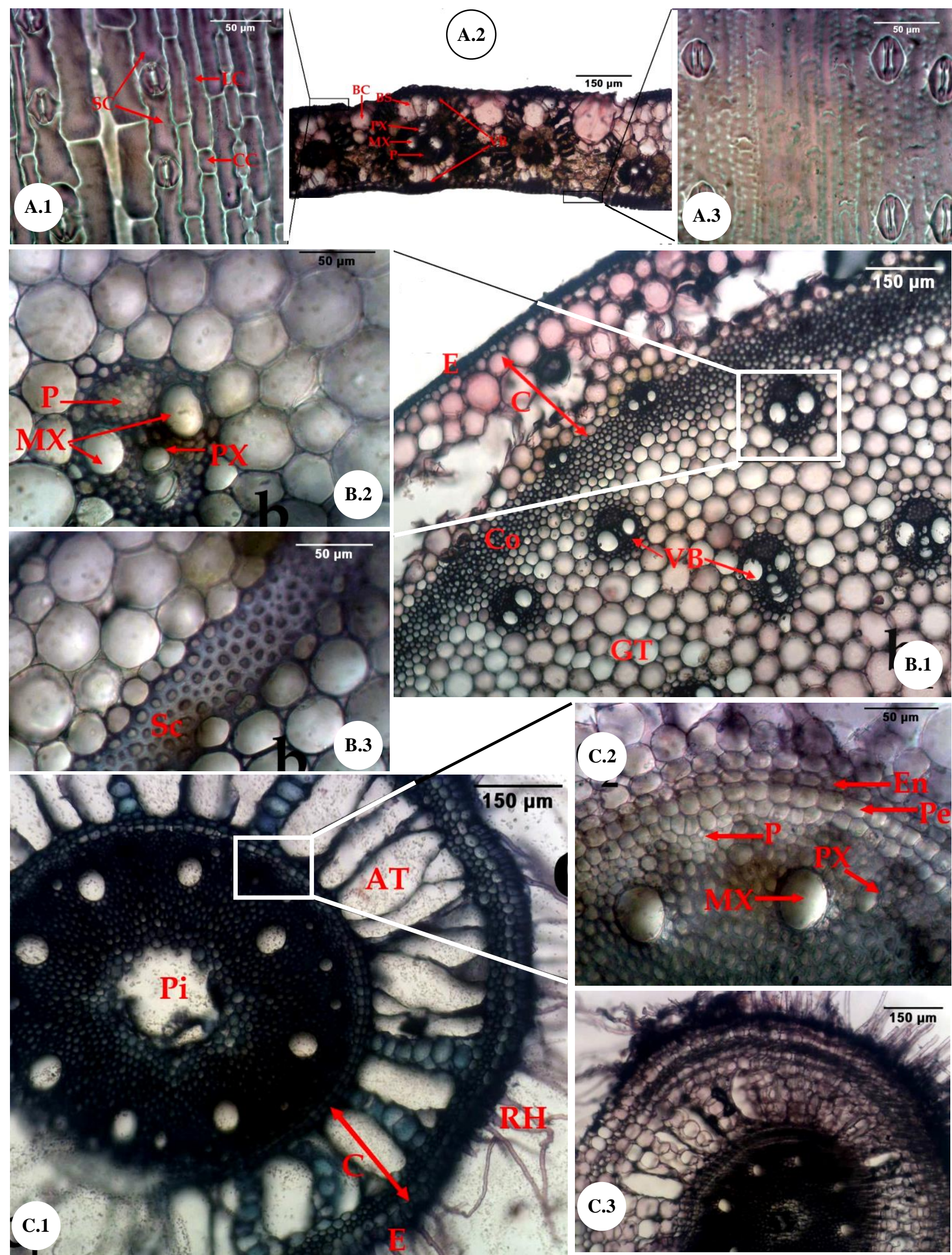

Figure 4.A-C. Anatomical features of Eleusine indica showing the leaf (A), culm x.s (B) and root x.s.(C) (AT: aerenchyma; BC: bulliform cells; BS: bundle sheath; C: cortex; Cc: cork cells; Co: collenchyma; E: epidermis; En: endodermis; GT: ground tissues; LC: long cells; MX: metaxylem; P:phoem; Pe: periycle; Pi: pith; PX: protoxylem; RH: root hairs; Sc: sclerenchyma; SC: subsidiary cells; VB: vascular bundles). 

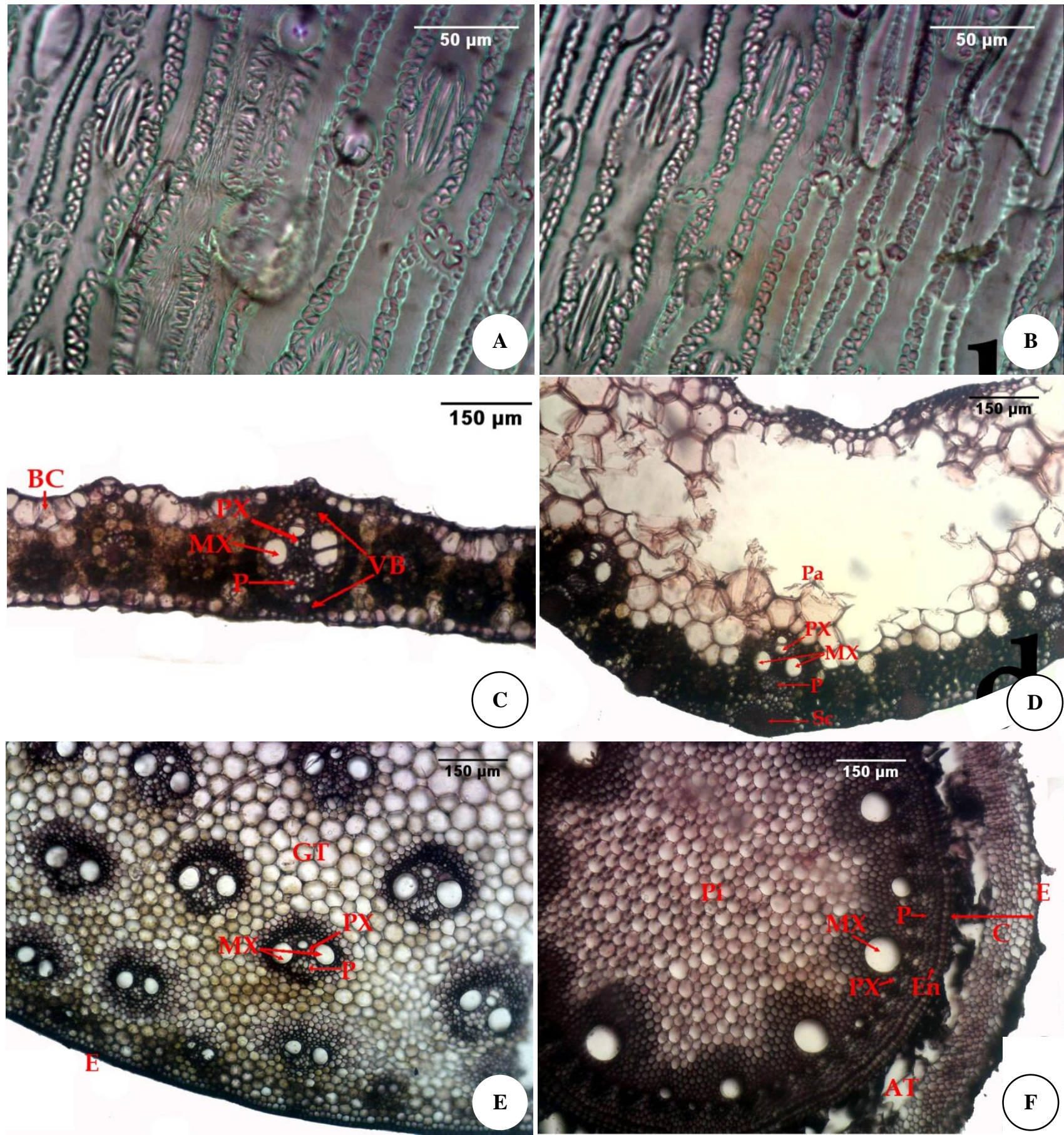

Figure 5.A-F. Anatomical features of Pennisetum purpureum showing the adaxial (A) and abaxial (B) epidermis, leaf blade (C) and midrib, (D), culm x.s (E) and root x.s. (F) (AT: aerenchyma; BC: bulliform cells; C: cortex; E: epidermis; En: endodermis; GT: ground tissues; MX: metaxylem; P:phoem; Pi: pith; PX: protoxylem; Sc: sclerenchyma; VB: vascular bundles).

On the other hand, the culm (Figure 5.E) exhibits a typical atactostele arrangement. The epidermis forms the outermost covering followed by ground tissues embedded with closed collateral vascular bundles. Several layers of collenchyma (sclerenchyma in older stem) from the periphery after the epidermis. The vascular bundles are greatly concentrated in the periphery with lesser concentrations toward the central core and are surrounded by large parenchyma cells. The leaf blade (Figure 5.C) has undivided mesophyll with regularly-spaced vascular bundles. Within the vascular bundles are the xylem at the upper portion and the phloem underneath. Bulliform cells occur on the upper epidermis at groups of 4-5 cells. The midrib (Figure 5.D), on the other hand, is much wider than the blade with its width mostly occupied by large parenchyma cells and the vascular bundles underneath near the lower epidermis. These vascular bundles were supported by several layers of sclerenchyma cells. Stomata 
are of gramineous type and are both found in upper (Figure 5.A) and lower (Figure 5.B) epidermis.

\section{Response of the local aquatic macrophytes to the phytoremediation treatment}

The responses of the local macrophytes to the phytoremediation set-up used in the study were speciesspecific as shown on how their morpho-anatomical features differed between the three sampling sites.

\section{Eichhornia crassipes (Mart) Solms.}

TrA samples of E. crassipes, the ones used in phytoremediation, were compared only with those in the nearby pond since none naturally occur in Balili River (Table 1). Plant height ranged from $8-20 \mathrm{~cm}$ with TrA samples being significantly longer but could just be attributed to plant's plasticity. Root-mass fraction, which signifies allocation of plants resources to root, did not differ among the samples. Root length ranged from 7-25 $\mathrm{cm}$ with lateral extent of $4-8 \mathrm{~cm}$. Specific root length (SRL) was significantly higher in TrA samples than Uncon samples. Higher SRL usually connotes higher nutrient uptake and higher growth rate (Perez-Harguindeguy et al. 2013) but the case of TrA samples is mainly attributed to their less dense root systems. On the other hand, the leaf blade was $3.5-7.5 \mathrm{~cm}$ long by $5.4-8.5 \mathrm{~cm}$ wide. Specific leaf area (SLA) was higher in Uncon samples, though not statistically significant. Higher SLA is positively correlated with fast growth rate and nutrient rich-environment, thus its difference between TrA and Uncon samples, if significant, could have signified stress brought by phytoremediation treatment. Also, leaf biomass, thickness, and stomatal density did not differ significantly between samples. Stomatal density in the abaxial (lower) epidermis is almost equal with the adaxial (upper) epidermis showing an amphistomatic distribution. This is contrary to the generalization that aquatic plants generally have epistomatic distribution or greater stomata in the upper than the lower epidermis.

Comparison of the morphological and anatomical features of E. crassipes between $\operatorname{TrA}$ and Uncon samples revealed no significant difference, statistically and structurally, showing that the phytoremediation treatment did not significantly affect the plant. Nonetheless, the characterization showed new and interesting information about $E$. crassipes such as SLA, root-mass fraction and the anatomy of the leaf, offshoot, and root.

\section{Amaranthus spinosus L.}

Results of the morphological comparison between the three samples were shown in Table 1. Plant height ranged from 0.45 to $1.75 \mathrm{~m}$ with significantly longer individuals from Balili samples. Root-mass fraction was significantly higher in TrA samples which indicate greater investment of the plant in the roots for nutrient absorption. This would also indicate the high organic matter in Balili River, wherein the plants here need not spend a lot of resources in their roots for absorption. Root depth ranged from 0.19 : $0.35 \mathrm{~m}$ while SRL at $3-9 \mathrm{mg} / \mathrm{mm}^{2}$ with no significant differences between the samples. However, lateral extent of the root was significantly higher in Balili samples while density of exploration@11-20 cm was significantly higher in TrA samples. This indicates different prevailing environmental factors eliciting two different response between $\operatorname{TrA}$ and Balili samples with the former focusing more resources for exploration while the latter for nutrient absorption. According to Alejar and Sese (1999), plants growing in drier areas tend to grow longer roots as exemplified by TrA samples. It was observed that wastewater supplied to the CWs were at least $20 \mathrm{~cm}$ from the surface, thus forcing the plants to allocate more resources in extending their roots to reach the water. On the other hand, the wider lateral extent of Balili samples is an indicator of high water and nutrient content on the upper surface layer of the soil. Balili samples also had wider stems and greater SLA than TrA and Uncon samples, indicative of the faster growth rate of the plant due to high nutrient and water content in the littoral zone of the river. The leaf blade was $3.6-12.8 \mathrm{~cm}$ long by $1.9: 6.3 \mathrm{~cm}$ wide while stomatal density ranged from 189-268 with an overall mean of $225 \mathrm{stoma} / \mathrm{mm}^{2}$. Stomata were observed only in the abaxial epidermis. From these results, it is apparent that $\operatorname{TrA}$ samples did not significantly differ from Uncon sites, and hence the phytoremediation treatment did not significantly affect the plant. It is readily apparent, though, that Balili samples are significantly larger with faster growth rate indicative of the high amount of organic pollutants in the river. Also, anatomical observation of $A$. spinosus from three collections sites did not reveal any structural differences that could hint any effect of the pollutants or the phytoremediation treatment.

\section{Eleusine indica (L.) Gaertn.}

Results of the morphological comparison between the three samples were shown in Table 1. Plants height of samples in the study ranged from 0.33: $0.92 \mathrm{~m}$ with significantly taller individuals from Balili samples. Rootmass fraction, on the other hand, was lower in TrA samples than those of the other two sites. This could be attributed to denser root system observed in Uncon and Balili samples. Root depth ranged from 0.17-0.33 m with lateral extent of 3-12 cm. Density of exploration showed that root biomass was greater in the upper $0: 10 \mathrm{~cm}$ layers of the soil with very low values below $20 \mathrm{~cm}$ depth which shows the relatively short system of this plant.

Balili samples were evidently stouter as indicated by their significantly thicker culm. Also, Balili samples had significantly larger blade and higher SLA than the other two samples. This could be readily attributed to the high organic matter content and water saturated condition of the littoral zone. Leaf blades measured at $14.7-43 \mathrm{~cm}$ long by $0.4-1 \mathrm{~cm}$ wide. SPA is significantly lowest in TrA samples which could indicate stress or unfavorable condition of the plants. This is most likely attributed to the relatively shorter root system of the plant that cannot penetrate deep enough to reach the water in the CW. Lamina and midrib thickness of the plant was also significantly lower in TrA samples. The stomatal density, on the other hand, did not differ significantly among samples. Stomatal density in the abaxial epidermis averaged at 77 stomata $/ \mathrm{mm}^{2}$ which much 
lower than that of adaxial epidermis at $140 \mathrm{stoma} / \mathrm{mm}^{2}$. This finding agrees with the conclusion of Zarinkamar (2006) that most species of Poaceae have higher stomatal density in the adaxial epidermis.

Anatomical characterization of $E$. indica revealed structural difference in roots among the three samples. Uncon and Balili samples have wide stretch of aerenchyma tissues in their cortex while TrA samples have normal parenchymatous cortex. This indicates inundated substrate in the uncontaminated site and Balili River while drier conditions in the treatment area. These result showed that E. indica was significantly affected by phytoremediation suffering significantly lower growth rate (as indicated by significantly lower SLA, leaf thickness, culm diameter) than those in the uncontaminated site. This could be attributed to the relatively short root system of the plant making it unable to tap into the water and nutrient in the wastewater within the constructed wetland. This is readily conceivable in the lack of aerenchyma in cortex of $\operatorname{TrA}$ samples while present in Uncon and Balili samples. This means that it's the phytoremediation set-up that affected the plant and not the pollutants. Therefore, it is recommended that phytoremediation set-up using $E$. indica should have shallower depth of their substrate.

\section{Pennisetum purpureum Schumach.}

Results of the comparison were presented in Table 1 . Plant height ranged from 1.2: $2.46 \mathrm{~m}$ with significantly taller samples from Balili River than TrA than Uncon samples. Root-mass fraction, SRL and density of exploration did not differ significantly while root depth and lateral extent are significantly lower in Uncon samples. The similarity in below-ground traits of TrA samples with Balili samples could be attributed to their similar substrate (sandy soil) which the roots can easily penetrate. This is in contrast with Uncon samples that have harder loamy soils. Culm diameter was also significantly thinner in Uncon samples.

The leaf blade was $31-106 \mathrm{~cm}$ long by $1-3.1 \mathrm{~cm}$ wide with significantly smaller values in Uncon samples. SPA, lamina and midrib thickness did not differ significantly between samples. On the other hand, leaf biomass and stomatal density were significantly lower in Uncon samples. In TrA and Balili samples, abaxial stomatal density was 116 stoma $/ \mathrm{mm}^{2}$ while much lower on adaxial epidermis at 81 and $91 \mathrm{stoma} / \mathrm{mm}^{2}$, respectively. Uncon samples had much lower values at 71 in abaxial and 62 stomata $/ \mathrm{mm}^{2}$ in adaxial epidermis. TrA and Balili samples exhibited hypostomatic stomatic distribution while Uncon samples exhibited amphistomatic (equal) distribution. The difference could be attributed to the prevailing environmental factors in the location site of the samples. The significantly lower stomatal density in Uncon samples could be attributed to the low light condition and relatively drier environment in this site. The uncontaminated site is from the slope of Mt. Jambo which is higher (=colder temp) and is usually covered with fog in the afternoon. Also, TrA samples and Balili sites are constantly saturated with wastewater thus water is not limiting. Beck (2010) found that lower stomatal density could arise from three factors namely low light condition, high atmospheric carbon dioxide concentrations and dry environment.

From these results, a clear picture is emerging. In almost half of the morphological features, TrA samples significantly differ with Uncon samples, its source, and through the course of the phytoremediation, treatment became more similar with the Balili samples: becoming as large and robust as the Balili samples. This change could be attributed, in lesser degree, to the environmental factors provided in the treatment site, namely, the sandy soil and the prevailing climatic conditions. In a greater degree, it is attributed to the nutrients in wastewater (that are actually the water pollutants) that are readily absorbed by the plants in their extensive root system. This is readily seen in the canonical correspondence analysis in Figure 7.6. Among the 6 environmental variables assumed to affect the traits of the plant, nitrate emerged as the primary factor affecting plant growth traits such as plant height, root specific length, root depth, root lateral extent, leaf biomass, and leaf length.

These results agree with the findings of Silveira et al. (2013) and Napaldet and Bout (on press) that this plant excels in absorption of nitrate and phosphates from wastewaters. These nutrients caused a faster growth rate and larger sizes of the plants under constructed wetland. But in terms of anatomical features, there were no structural differences between the three samples.

Thus, it could readily conclude that $P$. purpureum was affected, to a lesser extent by the phytoremediation treatment and in a greater extent by the pollutants in the $\mathrm{CW}$. The effects are in positive, beneficial ways contrary to that in E. indica. The success of $P$. purpureum in such treatment could be primarily attributed to its deep extensive root system enabling it to tap into the water and pollutants within the $\mathrm{CW}$. In fact, the water absorption of $P$. purpureum is very efficient that there was no dripping water from the $\mathrm{CW}$ after 8-10 days of introduction.

In summary, only E. indica and P. pupureum exhibited anatomical and physiological response that could be attributed to the phytoremediation set-up or pollutants therein as shown in Table 2. Individuals of $E$. indica subjected under phytoremediation had normal parenchymatous cortex and suffered significantly lower growth rate than those in the uncontaminated site. The effect on $P$. purpureum was opposite where higher biomass and growth rate was observed under phytoremediation treatment which could be directly attributed to the water pollutants that were absorbed as nutrients by the plant. The versatility of this plant could be attributed to its deep extensive root system making it ideal for constructed wetland treatments. On the other hand, A. spinosus and E. crassipes showed no significant morphological and anatomical difference between TrA and Uncon samples which indicate that these plants were not significantly affected by the phytoremediation treatments. 
Table 1. Biometric measurement of aquatic macrophytes

\begin{tabular}{|c|c|c|c|c|c|c|c|c|c|c|c|c|c|c|c|c|}
\hline \multirow{3}{*}{$\begin{array}{c}\text { Plant (functional) } \\
\text { traits }\end{array}$} & \multicolumn{4}{|c|}{ Eichhornia crassipes } & \multirow{2}{*}{\multicolumn{4}{|c|}{$\begin{array}{l}\text { Amaranthus spinosus } \\
\text { Collection site }\end{array}$}} & \multicolumn{4}{|c|}{ Eleusine indica } & \multicolumn{4}{|c|}{ Pennisetum purpureum } \\
\hline & \multicolumn{4}{|c|}{ Collection site } & & & & & \multicolumn{3}{|c|}{ Collection site } & \multicolumn{5}{|c|}{ Collection site } \\
\hline & $\begin{array}{l}\text { Treatment } \\
\text { area (mean) }\end{array}$ & $\begin{array}{c}\text { Un- } \\
\text { contaminated } \\
\text { site (mean) }\end{array}$ & T-Test & SD & $\begin{array}{c}\text { Treatment } \\
\text { area (mean) }\end{array}$ & $\begin{array}{c}\text { Un- } \\
\text { contaminated } \\
\text { site (mean) }\end{array}$ & $\begin{array}{c}\text { Balili river } \\
\text { (mean) }\end{array}$ & SD & $\begin{array}{c}\text { Treatment } \\
\text { area (mean) }\end{array}$ & $\begin{array}{c}\text { Un- } \\
\text { contaminated } \\
\text { site (mean) }\end{array}$ & $\begin{array}{c}\text { Balili river } \\
\text { (mean) }\end{array}$ & SD & $\begin{array}{c}\text { Treatment } \\
\text { area (mean) }\end{array}$ & $\begin{array}{l}\text { Un- } \\
\text { contaminated } \\
\text { site (mean) }\end{array}$ & $\begin{array}{c}\text { Balili river } \\
\text { (mean) }\end{array}$ & SD \\
\hline \multicolumn{17}{|l|}{ Whole plant traits } \\
\hline Plant height $(\mathrm{m})$ & 0.1289 & 0.1185 & $0.005^{* *}$ & \pm 0.0395 & $0.7708^{\mathrm{a}}$ & $0.7150^{\mathrm{a}}$ & $1.3529^{\mathrm{b}}$ & \pm 0.3795 & $0.5280^{\mathrm{ab}}$ & $0.4119^{\mathrm{a}}$ & $0.6106^{\mathrm{b}}$ & \pm 0.1341 & $1.8340^{\mathrm{b}}$ & $1.4700^{\mathrm{a}}$ & $2.1330^{c}$ & \pm 0.3280 \\
\hline Root-mass fraction & 0.5040 & 0.4736 & $0.291^{\mathrm{ns}}$ & \pm 0.0977 & $0.2480^{\mathrm{b}}$ & $0.2096^{\mathrm{ab}}$ & $0.1340^{\mathrm{a}}$ & \pm 0.0744 & $0.1121^{\mathrm{a}}$ & $0.2682^{\mathrm{b}}$ & $0.2169^{\mathrm{b}}$ & \pm 0.0915 & $0.4261^{\mathrm{a}}$ & $0.3665^{\mathrm{a}}$ & $0.3683^{\mathrm{a}}$ & \pm 0.1628 \\
\hline \multicolumn{17}{|l|}{$\begin{array}{l}\text { Below-ground } \\
\text { traits }\end{array}$} \\
\hline $\begin{array}{l}\text { Specific root } \\
\text { length }(\mathrm{m} / \mathrm{g})\end{array}$ & 24.0643 & 19.5193 & $0.010^{* *}$ & \pm 7.4234 & $6.2467^{\mathrm{a}}$ & $5.8041^{\mathrm{a}}$ & $6.6071^{\mathrm{a}}$ & \pm 1.9972 & $12.1696^{\mathrm{a}}$ & $8.7817^{\mathrm{a}}$ & $10.0758^{\mathrm{a}}$ & \pm 5.7937 & $23.1757^{\mathrm{a}}$ & $13.4537^{\mathrm{a}}$ & $21.1147^{\mathrm{a}}=$ & \pm 12.5529 \\
\hline Root depth(m) & 0.2090 & 0.1600 & $0.228^{\mathrm{ns}}$ & \pm 0.0526 & $0.2640^{\mathrm{a}}$ & $0.2750^{\mathrm{a}}$ & $0.3157^{\mathrm{a}}$ & \pm 0.0705 & $0.2850^{\mathrm{a}}$ & $0.2244^{\mathrm{a}}$ & $0.2800^{\mathrm{a}}$ & \pm 0.0723 & $0.4360^{\mathrm{ab}}$ & $0.3250^{\mathrm{a}}$ & $0.4660^{\mathrm{b}}$ & \pm 0.1088 \\
\hline Lateral extent $(m)$ & 0.0610 & 0.0513 & $0.228^{\mathrm{ns}}$ & \pm 0.0131 & $0.0800^{\mathrm{a}}$ & $0.1250^{\mathrm{ab}}$ & $0.1700^{\mathrm{b}}$ & \pm 0.0591 & $0.1085^{\mathrm{b}}$ & $0.0463^{\mathrm{a}}$ & $0.2178^{c}$ & \pm 0.0810 & $0.1590^{\mathrm{ab}}$ & $0.1167^{\mathrm{a}}$ & $0.2160^{\mathrm{b}}$ & \pm 0.0664 \\
\hline \multicolumn{17}{|l|}{$\begin{array}{l}\text { Density of } \\
\text { exploration } \\
\left(\mathrm{mg} / \mathrm{mm}^{2}\right)\end{array}$} \\
\hline - $1-10 \mathrm{~cm}$ & n.a. & n.a. & n.a. & n.a. & $0.0038^{\mathrm{a}}$ & $0.0022^{\mathrm{a}}$ & $0.0009^{\mathrm{a}}$ & \pm 0.0020 & $0.0021^{\mathrm{a}}$ & $0.0109^{\mathrm{b}}$ & $0.0007^{\mathrm{a}}$ & \pm 0.0050 & $0.0096^{\mathrm{a}}$ & $0.0077^{\mathrm{a}}$ & $0.0025^{\mathrm{a}}$ & \pm 0.0085 \\
\hline - $11-20 \mathrm{~cm}$ & n.a. & n.a. & n.a. & n.a. & $0.0011^{\mathrm{b}}$ & $0.0004^{\mathrm{ab}}$ & $0.00004^{\mathrm{a}}$ & \pm 0.0007 & $0.0004^{\mathrm{a}}$ & $0.0043^{\mathrm{b}}$ & $0.0002^{\mathrm{a}}$ & \pm 0.0029 & $0.0103^{\mathrm{a}}$ & $0.0078^{\mathrm{a}}$ & $0.0022^{\mathrm{a}}$ & \pm 0.0095 \\
\hline - $>20 \mathrm{~cm}$ & n.a. & n.a. & n.a. & n.a. & $0.00004^{\mathrm{a}}$ & $0.0001^{\mathrm{a}}$ & $0.00005^{\mathrm{a}}$ & \pm 0.0001 & $0.00009^{\mathrm{a}}$ & $0.0001^{\mathrm{a}}$ & $0.00004^{\mathrm{a}}$ & \pm 0.0001 & $0.0010^{\mathrm{a}}$ & $0.0003^{\mathrm{a}}$ & $0.0006^{\mathrm{a}}$ & \pm 0.0009 \\
\hline \multicolumn{17}{|l|}{ Culm (stem) } \\
\hline Diameter (mm) & n.a. & n.a. & n.a. & n.a. & $9.9000^{\mathrm{a}}$ & $12.6667^{\mathrm{a}}$ & $14.7143^{\mathrm{a}}$ & \pm 4.8609 & $2.7000^{\mathrm{a}}$ & $3.6250^{\mathrm{b}}$ & $4.1111^{\mathrm{b}}$ & \pm 0.8473 & $14.8000^{\mathrm{b}}$ & $9.0000^{\mathrm{a}}$ & $13.6000^{\mathrm{b}}=$ & \pm 3.0332 \\
\hline \multicolumn{17}{|l|}{ Leaf traits } \\
\hline Length(mm) & 46.4000 & 54.6250 & $0.041^{*}$ & \pm 10.8328 & $55.6000^{\mathrm{a}}$ & $63.3333^{\mathrm{a}}$ & $78.8571^{\mathrm{a}}$ & \pm 21.0420 & $245.6000^{\mathrm{a}} 2$ & $220.6250^{\mathrm{a}}$ & $320.5556^{\mathrm{b}}$ & \pm 71.8743 & $686.5000^{\mathrm{a}}$ & $517.567^{\mathrm{a}}$ & $966.0000^{\mathrm{b}}=$ & $\begin{array}{l} \pm 236.481 \\
3\end{array}$ \\
\hline Width (mm) & 66.1000 & 63.3750 & $0.874^{\mathrm{ns}}$ & \pm 7.5762 & $26.3000^{\mathrm{a}}$ & $34.5000^{\mathrm{ab}}$ & $40.1429^{\mathrm{b}}$ & \pm 11.3763 & $5.7000^{\mathrm{a}}$ & $5.1250^{\mathrm{a}}$ & $8.5556^{\mathrm{b}}$ & \pm 1.6726 & $22.8000^{\mathrm{b}}$ & $17.1667^{\mathrm{a}}$ & $21.2000^{\mathrm{ab}}=$ & \pm 4.3756 \\
\hline $\begin{array}{l}\text { Specific leaf } \\
\operatorname{area}\left(\mathrm{m}^{2} / \mathrm{kg}\right)\end{array}$ & 15.5020 & 23.9219 & $0.056^{\mathrm{ns}}$ & \pm 9.9727 & $21.8500^{\mathrm{a}}$ & $27.1146^{\mathrm{a}}$ & $62.1362^{\mathrm{b}}$ & \pm 18.6080 & $17.8243^{\mathrm{a}}$ & $25.6933^{b}$ & $30.9821^{\mathrm{c}}$ & \pm 5.6676 & $21.3702^{\mathrm{a}}$ & $23.3826^{\mathrm{a}}$ & $23.0520^{\mathrm{a}}=$ & \pm 7.352 \\
\hline Leaf biomass (mg) & 190.0000 & 137.5000 & $0.936^{\mathrm{ns}}$ & \pm 84.0168 & $50.0000^{\mathrm{a}}$ & $58.0888^{\mathrm{a}}$ & $32.9066^{\mathrm{a}}$ & \pm 24.0909 & $70.0000^{\mathrm{b}}$ & $37.5000^{\mathrm{a}}$ & $77.7778^{\mathrm{b}}$ & \pm 25.8872 & $710.0000^{\mathrm{b}}$ & $366.6667^{\mathrm{a}}$ & $770.0000^{\mathrm{b}}=$ & $\begin{array}{l} \pm 311.423 \\
5\end{array}$ \\
\hline Lamina thickness $(\mu \mathrm{m})$ & 641.9810 & 480.8808 & $0.694^{\mathrm{ns}}$ & \pm 89.5909 & $264.8440^{\mathrm{a}} \quad 2$ & $237.3373^{\mathrm{a}}$ & $245.3630^{\mathrm{a}}$ & \pm 31.8794 & $+151.5230^{\mathrm{a}}$ & $257.4790^{\mathrm{b}}$ & $262.0280^{\mathrm{b}}$ & \pm 62.0682 & $225.5875^{\mathrm{a}}$ & $210.5555^{\mathrm{a}}$ & $203.5345^{\mathrm{a}}=$ & \pm 35.9696 \\
\hline Midrib thickness ( $\mu \mathrm{m}$ & 641.9810 & 480.8808 & $0.694^{\mathrm{ns}}$ & \pm 89.5909 & $617.3587^{a}$ & $629.1530^{\mathrm{a}}$ & $732.3773^{b}$ & \pm 62.9406 & $6308.7353^{\mathrm{a}} 7$ & $749.4913^{b}$ & $678.1985^{\mathrm{b}}$ & \pm 218.8466 & $637.2690^{\mathrm{a}}$ & $693.0703^{a}$ & $678.1985^{\mathrm{a}}=$ & \pm 38.8218 \\
\hline $\begin{array}{l}\text { Abaxial stomatal } \\
\text { density }\left(\text { stoma } / \mathrm{mm}^{2}\right)\end{array}$ & 101.3226 & 111.0066 & $0.136^{\mathrm{ns}}$ & \pm 13.4779 & $216.9214^{\mathrm{a}}$ & $238.1621^{\mathrm{a}}$ & $219.5706^{a}$ & \pm 27.7538 & $84.0515^{\mathrm{a}}$ & $77.4554^{\mathrm{a}}$ & $70.5748^{a}$ & \pm 9.2785 & $116.2853^{\mathrm{b}}$ & $70.8063^{\mathrm{a}}$ & $116.1765^{\mathrm{b}}=$ & \pm 23.7782 \\
\hline $\begin{array}{l}\text { Adaxial stomatal } \\
\text { density (stoma/mm²) }\end{array}$ & 103.0250 & 107.1358 & $0.155^{\mathrm{ns}}$ & \pm 11.3235 & 0.00 & 0.00 & 0.00 & 0.00 & $141.0864^{\mathrm{a}}$ & $131.4882^{\mathrm{a}}$ & $147.8462^{\mathrm{a}}$ & \pm 11.6396 & $80.5722^{\mathrm{a}}$ & $61.8052^{\mathrm{a}}$ & $90.6571^{\mathrm{a}}=$ & \pm 21.2179 \\
\hline
\end{tabular}


Table 2. Summary of the observed anatomical and physiological traits in the studied macrophytes across sampling sites

\begin{tabular}{|c|c|c|c|}
\hline \multirow{2}{*}{ Plant samples } & \multicolumn{3}{|c|}{ Sampling sites } \\
\hline & Uncontaminated samples & Treatment site samples & Balili samples \\
\hline \multicolumn{4}{|c|}{ Eichhornia crassipes } \\
\hline Root anatomy & $\begin{array}{l}\text { Siphonosteles with wide aerenchyma tissues in the } \\
\text { cortex }\end{array}$ & $\begin{array}{l}\text { Siphonosteles with wide aerenchyma tissues in the } \\
\text { cortex }\end{array}$ & Not applicable \\
\hline Stem anatomy & $\begin{array}{l}\text { Specialized stem offshoot with starch grains, } \\
\text { aerenchymatous, atactostele }\end{array}$ & $\begin{array}{l}\text { Specialized stem offshoot with starch grains, } \\
\text { aerenchymatous, atactostele }\end{array}$ & Not applicable \\
\hline Leaf anatomy & $\begin{array}{l}\text { Specialized petiole bulbous with wide aerenchyma } \\
\text { Isobilateral with } 2 \text { layers of vascular bundles }\end{array}$ & $\begin{array}{l}\text { Specialized petiole bulbous with wide aerenchyma } \\
\text { Isobilateral with } 2 \text { layers of vascular bundles }\end{array}$ & Not applicable \\
\hline \multicolumn{4}{|c|}{ Amaranthus spinosus } \\
\hline Root anatomy & $\begin{array}{l}\text { Anomalous secondary growth: successive } \\
\text { supernumerary cambia }\end{array}$ & $\begin{array}{l}\text { Anomalous secondary growth: successive } \\
\text { supernumerary cambia }\end{array}$ & $\begin{array}{l}\text { Anomalous secondary growth: successive } \\
\text { supernumerary cambia }\end{array}$ \\
\hline Stem anatomy & $\begin{array}{l}\text { Anomalous secondary growth: successive } \\
\text { supernumerary cambia }\end{array}$ & $\begin{array}{l}\text { Anomalous secondary growth: successive } \\
\text { supernumerary cambia }\end{array}$ & $\begin{array}{l}\text { Anomalous secondary growth: successive } \\
\text { supernumerary cambia }\end{array}$ \\
\hline Leaf anatomy & Dorsiventral & Dorsiventral & Dorsiventral \\
\hline \multicolumn{4}{|l|}{ Eleusine indica } \\
\hline Root anatomy & Siphonostele with aerenchymatous cortex & $\begin{array}{l}\text { Siphonostele with normal parenchymatous cortex, lesser } \\
\text { lateral extent }\end{array}$ & $\begin{array}{l}\text { Siphonostele with aerenchymatous cortex, higher } \\
\text { specific root length }\end{array}$ \\
\hline Stem anatomy & Atactostele & atactostele, narrower diameter & atactostele \\
\hline Leaf anatomy & Isobilateral & Isobilateral & isobilateral, higher specific leaf area \\
\hline \multicolumn{4}{|c|}{ Pennisetum purpureum } \\
\hline Root anatomy & $\begin{array}{l}\text { Siphonostele with aerenchymatous cortex, shallower } \\
\text { roots }\end{array}$ & Siphonostele with aerenchymatous cortex & Siphonostele with aerenchymatous cortex \\
\hline Stem anatomy & Atactostele, narrower diameter & Atactostele & Atactostele \\
\hline Leaf anatomy & Isobilateral, lower stomatal density & isobilateral & Isobilateral \\
\hline
\end{tabular}




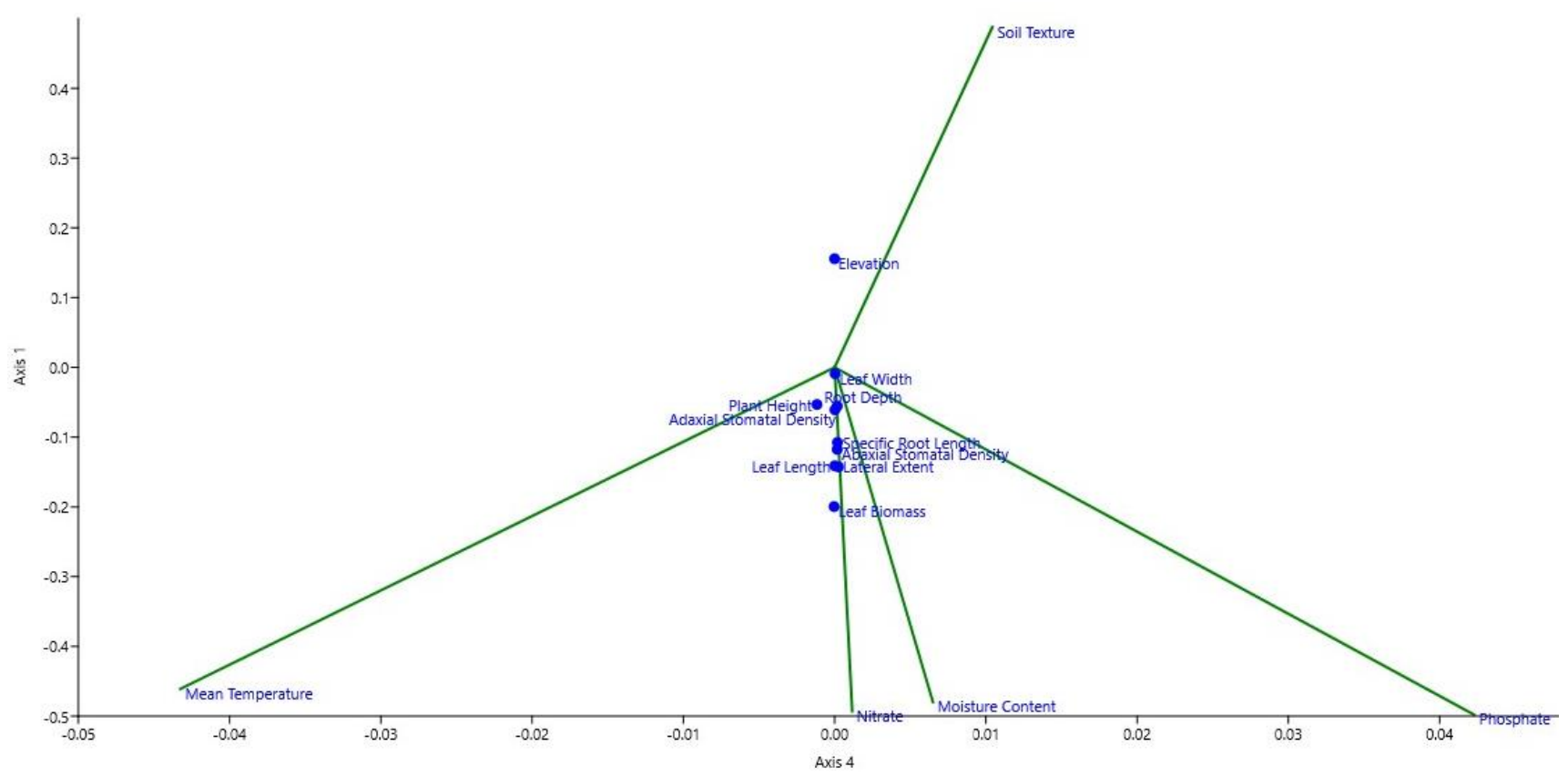

Figure 6. Result of the Canonical Correspondence Analysis showing how the environmental variables (soil texture, elevation, moisture content, temperature, nitrate, and phosphate) affected the morpho-anatomical traits of $P$. purpureum

In conclusion, interesting anatomical features in the studied macrophytes namely A. spinosus, E. crassipes, E. indica, and $P$. purpureum were discovered. Anatomical features $P$. purpureum was first reported in this study. Anomalous secondary growth was discovered in roots and stems of A. spinusus while $P$. purpureum exhibited common monocot anatomy with siphonostele roots, atactostele stem and undivided mesophyll in leaf. Interesting observations were also noted in E. crassipes including the isobilateral anatomy of the leaf where there are two palisade layers under each epidermis and the presence of two layers of vascular bundles, each associated with the parallel palisade layers. Lastly, E. indica exhibited root, stem and leaf anatomy that was consistent with those previously described by Saw (2011). Results showed that the response of the aquatic macrophytes toward phytoremediation treatments or the pollutants in the $\mathrm{CW}$ was species-specific. In A. spinosus and E. crassipes, there were no significant morphological and anatomical difference between $\operatorname{TrA}$ and Uncon samples which shows that these plants were not significantly affected by the phytoremediation treatments. However, E. indica and $P$. purpureum were shown to be significantly affected by the phytoremediation treatment but in contrasting ways. $E$. indica under phytoremediation suffered significantly lower growth rate than those in the uncontaminated site. Also, the root cortex between samples differs where samples under phytoremediation have no aerenchyma while those in uncontaminated site and Balili River have. This indicates inundated substrate in uncontaminated site and Balili River while drier condition in the treatment area. These observations could be attributed to relatively short root system of the plant making it unable to tap into the water and nutrients in the wastewater within the constructed wetland. This means that it is not the pollutants that significantly affect the plant but, instead, the substrate setup. On the other hand, $P$. purpureum exhibited higher biomass and growth rate under phytoremediation treatment which is directly attributed to the water pollutants that were absorbed as nutrients by the plants. The versatility of this plant could be attributed to its deep extensive root system making it ideal for constructed wetland treatments.

\section{ACKNOWLEDGEMENTS}

This study is part of the Ph.D. Dissertation funded by SEARCA thru their Ph.D. Research Program and DOSTASTHRDP through Student Research Support Fund (SRSF). The authors would also to express their appreciation to all individuals who extended help of any kind in making this work possible. Special mention to Edgar Alimambo for all the help during the data gathering part and to Ma'am Maricel Guron for the maps.

\section{REFERENCES}

Alkorta I, Hernández-Allica J, Becerril JM, Amezaga I, Albizu I, Garbisu C. 2004. Recent findings on the phytoremediation of soils contaminated with environmentally toxic heavy metals and metalloids such as zinc, cadmium, lead, and arsenic. Reviews in Environ Sci Biotechnol 3 (1): 71-90. 
Alonzo-Alejar AM, Dionisio-Sese ML. 1999. Fundamentals of Plan Physiology. Plant Physiology Society of the Philippines. Pasig City, Metro Manila.166 pp.

Beck CB. 2010. An Introduction to Plant Structure and Development. New York, USA: Cambridge University Press.

Bini C, Wahsha M, Fontana S, Maleci L. 2012. Effects of heavy metals on morphological characteristics of Taraxacum officinale Web growing on mine soils in NE Italy. J Geochemical Explor123: 101-108.

Hanif U, Khalid M, Ishtiaq S, Shaheen S, Cheema TA, Achakzai AKK 2017. Assessment of Morphoanatomical Study of Eichhornia crassipes (Mart) Solms. and Nymphae arubra Roxb. Ex. Andrews. A Step toward Minimizing the Adulterations in Drug Plants. Transylvanian Rev 25(18): 4738-4744.

Mganga N, Manoko MLK, Rulangaranga ZK. 2011. Classification of plants according to their heavy metal content around North Mara Gold Mine, Tanzania: implication for phytoremediation. Tanzania J Sci 37: 110-119.

Pancho JV, Obien SR. 1995. Manual of Ricefield Weeds in the Philippines. Philippines Rice Research Institute Moñuz, Nueva Ecija, Philippines.
Pérez-Harguindeguy N, Díaz S, Garnier E et al. 2016. New handbook for standardized measurement of plant functional traits worldwide. Aust J Bot 64:715-716.

Rapoport HF, Loomis RS. 1986. Structural aspects of root thickening in Beta vulgaris L.: Comparative thickening in sugarbeet and chard. Bot Gazette 147(3): 270-277.

Saw KO. 2011. Morphological and Microscopical characters of Eleusine indica (L.) Gaertn. Universities Res J 4(1): 225-244.

Silveira ML, Vendramini JMB, Sui X. et al. 2013. Screening perennial warm-season bioenergy crops as an alternative for phytoremediation of excess soil P. Bioenergy Res 6: 469.

Tulod AM, Castillo AS, Carandang WM, Pampolina NM. Growth performance and phytoremediation of Pongamia pinnata (L.) Pierre, Samanea saman (Jacq.) Merr. and Vitex parviflora Juss. In copper contaminated soil amended with zeolite and VAM. Asia Life Sci 21(2): 499-522.

Wazir R, Muhammad A, Subhan M, Khan I, Ali M. 2014. Morphoanatomical features of weed flora of rainfed maize field in Mir Ali, North Waziristan Agency, Pakistan. Pak J Weed Sci Res 20(3): 385403.

Zarinkamar F. 2006. Density, size and distribution of stomata in different monocotyledons. Pak J Biol Sci 9 (9): 1650-1659. 